CZU 341.24:061.1EU

https://doi.org/10.52507/2345-1106.2021-2.06

SUPORTUL JURIDICO-LEGAL DE FUNCȚIONARE A UNIUNII EUROPENE

JUC Victor,

doctor habilitat în politologie, profesor universitar, Institutul de Cercetări Juridice, Politice și Sociologice https://orcid.org/0000-0002-4413-2940

DIACON Maria

doctor în științe politice, conferențiar universitar, Institutul de Cercetări Juridice, Politice și Sociologice https://orcid.org/0000-0002-3306-9886

CATAN Anastasia, doctor în drept, lector universitar, Universitatea de Studii Europene din Moldova https://orcid.org/ 0000-0003-4389-225 


\title{
REZUMAT
}

Studiul reprezintă analiza suportului juridico-legal de creare și funcționare a Uniunii Europene și oferă posibilitatea cunoașterii structurii acesteia, contribuind la definirea și înțelegerea obiectivelor Tratatelor de la Maastricht și de la Amsterdam cu privire la organizarea și funcționarea Uniunii Europene, facilitând identificarea caracteristicilor Tratatului de la Nisa și ale Convenției privind viitorul Europei și oferind cunoașterea noului sistem de organizare și funcţionare a Uniunii

Europene prin prisma prevederilor Tratatului de la Lisabona.

Cuvinte-cheie: tratate, proces de integrare, instituții, politici, programe

\section{LEGAL SUPPORT FOR THE FUNCTIONING OF THE EUROPEAN UNION}

\author{
JUC Victor, \\ Doctor habilitate in political science, university professor, \\ Institute of Legal, Political and Sociological Research \\ https://orcid.org/0000-0002-4413-2940 \\ DIACON Maria \\ $\mathrm{PhD}$ in political science, associate professor, \\ Institute of Legal, Political and Sociological Research \\ https://orcid.org/0000-0002-3306-9886
}

CATAN Anastasia,

$\mathrm{PhD}$ of law, university lecturer, University of European Studies of Moldova https://orcid.org/ 0000-0003-4389-225

\section{SUMMARY}

The study represents the analysis of the legal support for the creation and functioning of the European Union and offers the possibility to know its structure, contributing to the definition and understanding of the objectives of the Maastricht and Amsterdam Treaties on the organization and functioning of the European Union. Nice and the Convention on the Future of Europe and providing information on the new system of organization and functioning of the Union in the light of the provisions of the Treaty of Lisbon.

Key words: treaties, integration process, institutions, policies, programs

Tratatul privind Uniunea Europeană, semnat la Maastricht la 7 februarie 1992, a intrat în vigoare la 1 noiembrie 1993. Instituind o Uniune Europeană, tratatul de la Maastricht a marcat o nouă etapă în procesul de creare a „unei uniuni din ce în ce mai strânse între popoarele Europei”. Uniunea Europeană este construită având la bază Comunitătilie Europene [1], completate de politici și forme de cooperare instaurate prin Tratatul privind Uniunea Europeană. Uniunea dispunea de un cadru instituțional unic alcătuit din Consiliu, Parlamentul European, Comisia Europeană, Curtea de Justiție și Curtea de Conturi care, fiind în acel moment singurele „,instituții” ale Uniunii, în sensul strict al cuvântului, își exercitau atribuțiile în conformitate cu dispozițiile tratatelor. Tratatul a instituit un Comitet economic și social și un Comitet al regiunilor, ambele exercitând funcții consultative. Un Sistem European al Băncilor Centrale și o Bancă Centrală Europeană au fost înființate conform procedurilor prevăzute în tratat și s-au adăugat instituțiilor financiare preexistente, care sunt Banca Europeană de Investiții și Fondul European de Investiții.

Uniunii Europene, instituite prin Tratatul de la Maastricht, i s-a atribuit competențe clasificate în trei mari grupe, denumite în mod obişnuit ,,piloni”: cel dintâi „pilon” era constituit din Comunitățile Europene, în cadrul cărora competențele care făcuseră obiectul unui transfer de suveranitate a statelor membre în domeniile aflate sub incidența tratatului erau exercitate de instituțiile comunitare; al doilea „pilon” era format din politica externă și de securitate comună prevăzută la capitolul V din tratat;. al treilea ,pilon” era constituit din cooperarea în domeniul justiției și al afacerilor interne prevăzută la capitolul VI din tratat. Prin dispozițiile capitolelor V și VI, se instituia o cooperare de tip interguvernamental, care utiliza instituțiile comune și care era dotată cu anumite elemente supranaționale, în special asocierea Comisiei Europene și consultarea Parlamentului European.

Conform primului pilon, Comunitatea avea misiunea de a asigura buna functionare a pieței unice și, printre altele, o dezvoltare armonioasă, echilibrată și durabilă a activităților economice, un nivel ridicat de ocupare a forței de muncă și de protecție socială şi egalitatea între bărbați și femei. Comunitatea urmărea aceste obiective, în limitele competențelor care îi erau încredințate, prin instituirea unei piețe comune și a unor măsuri conexe menționate la articolul 3 din Tratatul Comunităților Europene, precum și prin instaurarea unei politici economice și a unei monede unice menționate la articolul 4. Acțiunea Comunității trebuia să respecte principiul proporționalității și, în domeniile care nu intrau în competența sa exclusivă, principiul subsidiarității 
(articolul $5 \mathrm{CE}$ ).

Cel de-al doilea pilon al tratatului menționa că misiunea Uniunii era aceea de a defini și de a pune în aplicare, conform unei metode de tip interguvernamental, o politică externă și de Securitate [2]. Statele membre trebuiau să sprijine în mod activ și fără rezerve această politică, într-un spirit de loialitate şi de solidaritate reciprocă. Printre altele, aceasta avea ca obiective: salvgardarea valorilor comune, a intereselor fundamentale, a independenței și a integrității Uniunii, în conformitate cu principiile Cartei Naţiunilor Unite; consolidarea securității Uniunii sub toate formele; promovarea cooperării internaționale; dezvoltarea și consolidarea democrației și a statului de drept, precum și respectarea drepturilor omului și a libertăţilor fundamentale.

Cooperarea în domeniul justiţiei şi al afacerilor externe (al treilea pilon) sublinia că sarcina Uniunii Europene era aceea de a elabora o acțiune comună în aceste domenii conform unei metode de tip interguvernamental [3] în vederea realizării obiectivului de a oferi cetățenilor un nivel ridicat de protecție într-un spațiu de libertate, de securitate și de justiţie. Aceasta se referea la următoarele domenii: reguli de trecere a frontierelor externe ale Comunității și de consolidare a controalelor; lupta împotriva terorismului, a infracțiunilor grave, a traficului de droguri și a fraudei la nivel internațional; cooperarea judiciară în materie penală şi civilă; crearea unui Oficiu European de Poliţie (Europol) dotat cu un sistem de schimb de informaţii între polițiile naționale; lupta împotriva imigrației ilegale; politica comună în domeniul azilului.

Tratatul de la Amsterdam de modificare a Tratatului privind Uniunea Europeană, a tratatelor de instituire a Comunităților Europene și a anumitor acte conexe, semnat la Amsterdam la 2 octombrie 1997, a intrat în vigoare la 1 mai 1999. În ceea ce privește obiectivele, sa pus un accent deosebit pe o dezvoltare echilibrată și durabilă și pe un nivel ridicat de ocupare a forței de muncă. S-a instituit un mecanism de coordonare a politicilor de ocupare a forței de muncă din statele membre, precum și posibilitatea de a lua anumite măsuri comunitare în acest domeniu. Acordul privind politica socială a fost integrat în Tratatul Comunității Europene cu câteva îmbunătătiri. De atunci, metoda comunitară sa aplicat în domenii importante care țineau până în acel moment de ,cel de-al treilea pilon”, cum ar fi azilul, imigrația, trecerea frontierelor externe, lupta împotriva fraudei, cooperarea vamală și cooperarea judiciară în materie civilă, precum și unei părţi importante a cooperării „Schengen”, acquis-ul lui fiind preluat de Uniunea Europeană.

Cooperarea interguvernamentală în domeniul cooperării judiciare penale și polițienești a fost consolidată prin definirea unor obiective și sarcini precise, precum și prin crearea unui nou instrument juridic analog unei directive. Instrumentele politicii externe și de securitate comună au fost dezvoltate ulterior, în special prin crearea unui nou instrument, strategia comună, a unei noi funcții, ,Secretarul General al Consiliului responsabil pentru PESC", și a unei noi structuri, „Unitatea de planificare politică și de alertă rapidă"

În cadrul procedurii de codecizie, care a fost extinsă la 15 temeiuri juridice existente în tratatul Comunităţii Europene, Parlamentul European și Consiliul deveneau colegiuitori, practic pe poziție de egalitate. $\mathrm{Cu}$ singurele excepții referitoare la politica agricolă și la politica din domeniul concurenței, procedura de codecizie se aplica tuturor domeniilor în care Consiliul era abilitat să ia decizii cu majoritate calificată. În patru cazuri (articolele 18, 42 și 47, precum și articolul 151 privind politica din domeniul culturii, care a rămas nemodificat), procedura de codecizie se combina cu necesitatea unei decizii unanime a Consiliului. Celelalte domenii legislative supuse unanimității nu țineau de codecizie.

În afara votului de aprobare a Comisiei în calitate de colegiu, Parlamentul European exercita și un vot de aprobare prealabilă a președintelui desemnat al viitoarei Comisii (articolul 214). În ceea ce privește procedura pentru alegerea Parlamentului European prin sufragiu universal direct (articolul 190 din tratatul Comunității Europene), competența Comunităţii de a adopta principii comune s-a adăugat competenței existente de a adopta o procedură uniformă. În același articol, a fost inserat un temei juridic care permitea adoptarea unui statut unic al deputaților. $\mathrm{Cu}$ toate acestea, continua să lipsească o dispoziție care să permită luarea de măsuri în vederea dezvoltării partidelor politice la nivel european (a se vedea articolul 191).

Pentru prima dată, tratatele cuprindeau dispoziţii generale care permiteau, în anumite condiții, unui anumit număr de state membre să se prevaleze de instituţiile comune pentru a organiza o cooperare consolidată între ele. Această posibilitate s-a adăugat cazurilor de cooperare consolidată reglementate de dispoziții specifice, cum ar fi uniunea economică și monetară, crearea unui spațiu de libertate, securitate și justiţie, precum și integrarea acquis-ului așa-numitei cooperări „Schengen”. Domeniile care puteau face obiectul unei cooperări consolidate erau reprezentate de cel de-al treilea pilon și, în condiții foarte stricte, de domeniile care nu țineau de competența exclusivă comunitară. Condițiile pe care trebuia să le satisfacă orice cooperare consolidată, precum și mecanismele de decizie prevăzute erau concepute astfel încât să garanteze că această nouă modalitate a procesului de integrare va rămâne o soluție excepțională și că nu va putea fi utilizată decât pentru a realiza progrese în cadrul procesului de integrare, nu pentru a regresa.

Tratatul de la Amsterdam a eliminat din tratatele europene orice dispoziție devenită caducă sau depășită în timp, evitând, în același timp, ca efectele juridice care decurgeau din aceasta în trecut să fie afectate de eliminare. Acesta prevedea şi o nouă numerotare a tratatelor. Din motive juridico-politice, tratatul a fost semnat și supus ratificării sub formă de amendamente la tratatele în vigoare.

Prin tratatul de la Amsterdam au fost trasate câteva reforme instituţionale în perspectiva viitoarelor extinderi. Astfel a fost fixat la 700 numărul maxim de membri în Parlamentul European, în conformitate cu solicitarea acestuia (articolul 189). Componența Comisiei și problema ponderării voturilor au făcut obiectul unui 
„protocol privind instituțiile” anexat la tratat. În temeiul dispozițiilor acestuia, într-o Uniune extinsă la maximum 20 de state membre, Comisia urma să fie alcătuită dintrun reprezentant din fiecare stat membru, cu condiţia ca la data respectivă, ponderarea voturilor în sânul Consiliului să fi fost modificată. În orice caz, cu cel puțin un an înainte de aderarea unui al 21-lea stat membru, o nouă Conferință Interguvernamentală trebuia să recurgă la o reexaminare completă a dispozițiilor instituționale din tratate. Votul cu majoritate calificată în Consiliu era prevăzut pentru mai multe temeiuri juridice nou-create de Tratatul de la Amsterdam. $\mathrm{Cu}$ toate acestea, dintre politicile comunitare existente, numai în cazul domeniului politicii privind cercetarea au apărut noi cazuri de vot cu majoritate calificată, celelalte politici necesitând încă luarea deciziilor cu unanimitate de voturi.

Acquis-ul practicii comunitare în domeniul aplicării principiului subsidiarității a fost inclus într-un protocol cu privire la acest subiect. Transparența a fost îmbunătățită prin noi dispoziții privind accesul la documente (articolul 255) şi prin deschiderea lucrărilor Consiliului în domeniul legislativ [articolul 207 alineatul (3)].

Parlamentul European era consultat pe subiectele agendei înaintea convocării unei conferințe interguvernamentale. În plus, Parlamentul European era asociat acestor conferințe interguvernamentale conform unor formule ad-hoc; în decursul ultimelor trei dintre acestea, Parlamentul a fost reprezentat, după caz, de către președinte sau de către doi deputați în Parlamentul European [4].

Problemele nesoluționate de Tratatul de la Amsterdam trebuiau rezolvate prin Tratatul de la Nisa. $\mathrm{Cu}$ toate acestea, tratatul a pregătit doar parțial Uniunea Europeană pentru extinderile importante spre est și sud de la 1 mai 2004 și 1 ianuarie 2007. Prin urmare, ca răspuns la întrebările ridicate în Declaraţia de la Leaken din 15 decembrie 2001, Conventia privind viitorul Europei a încercat să elaboreze un nou temei juridic pentru Uniune, sub forma Tratatului de instituire a unei Constituții pentru Europa. În urma referendumurilor cu rezultate negative organizate în două state membre, acest tratat nu a fost ratificat.

Tratatul de la Nisa a fost semnat la 26 februarie 2001 şi a intrat în vigoare la 1 februarie 2003. În conformitate cu Concluziile Consiliului European de la Helsinki din 1999, Uniunea Europeană trebuia să fie capabilă să primească, de la sfârşitul anului 2002, noile state membre pregătite pentru aderare. Deoarece doar două dintre statele solicitante aveau o populație mai mare decât media statelor membre de la vremea respectivă, ponderea politică a țărilor cu o populație mai mică trebuia să crească considerabil. Prin urmare, Tratatul de la Nisa viza să sporească eficiența și legitimitatea instituțiilor comunitare și să pregătească Uniunea Europeană pentru următoarea sa mare extindere.

În cadrul Conferințelor interguvernamentale de la Maastricht și Amsterdam [1], au fost abordate o serie de probleme instituționale, fără ca ele să fie însă rezolvate în mod satisfăcător (problemele nesoluționate de Tratatul de la Amsterdam): dimensiunea și componența Comisiei, ponderarea voturilor în Consiliu și extinderea votului cu majoritate calificată. Pe baza unui raport al Președinției finlandeze, Consiliul European de la Helsinki a decis, la sfârşitul anului 1999, ca problemele nesoluționate de Tratatul de la Amsterdam şi toate celelalte modificări necesare pentru pregătirea extinderii să fie abordate în cadrul unei Conferințe Interguvernamentale.

Conferința Interguvernamentală a fost deschisă la 14 februarie 2000 și și-a încheiat activitatea la Nisa la 10 decembrie 2000. Aceasta a ajuns la un acord asupra chestiunilor instituționale menționate mai sus, precum și asupra altor puncte, printre care o nouă repartizare a mandatelor în Parlamentul European, o cooperare consolidată mai flexibilă, monitorizarea drepturilor și valorilor europene și consolidarea sistemului judiciar al Uniunii Europene.

În urma examinării sistemului de vot în Consiliu, a componenței Comisiei și, într-o anumită măsură, a repartizării mandatelor necesare în Parlamentul European, Conferința Interguvernamentală a considerat că principalul imperativ era modificarea ponderii relative a statelor membre, un subiect care nu mai fusese abordat de nici o Conferință Interguvernamentală de la intrarea în vigoare a Tratatului de la Roma. Erau prevăzute două metode de definire a votului cu majoritate calificată: un nou sistem de ponderare (o adaptare a sistemului existent) sau aplicarea unei majorități duble (de voturi și de populație), aceasta din urmă fiind propusă de Comisie și susţinută de Parlament. Conferința Interguvernamentală a ales prima opțiune. Deși numărul de voturi a crescut pentru toate statele membre, partea care le revine celor mai populate state membre a scăzut de la $55 \%$ din voturi la $45 \%$ în urma aderării celor noi zece state membre și la 44,5\% la 1 ianuarie 2007. De aceea, a fost introdus ,dispozitivul de siguranță" demografică prin care un stat membru poate solicita să se verifice dacă majoritatea calificată reprezintă cel puțin $62 \%$ din populația totală a Uniunii. În cazul în care această condiție nu este îndeplinită, decizia nu este adoptată.

Pe segmentul de funcționalitate a Comisiei Europene, Tratatul de la Nisa a decis că din 2005, statele membre au dreptul la câte un singur comisar. Consiliul are competența de a decide, în unanimitate, numărul de comisari, precum și sistemul de rotație a acestora, astfel încât fiecare Comisie să reflecte dimensiunea demografică și geografică a statelor membre. Tratatul de la Nisa conferea Președintelui Comisiei competența de a aloca responsabilitățile comisarilor și de a le redistribui pe parcursul mandatului, precum și de a-și alege numărul dorit de vicepreședinți.

Pe segmentul de funcţionalitate a Parlamentului European, subliniem următoarele: Tratatul de la Amsterdam a stabilit numărul maxim de deputați în Parlamentul European la 700. La Nisa, Consiliul European a considerat necesar, în perspectiva extinderii, să revizuiască numărul de deputați în PE pentru fiecare stat membru. Noua componență a Parlamentului a fost utilizată, de asemenea, pentru a contrabalansa ponderarea modificată a voturilor în Consiliu. Astfel, numărul maxim de deputați europeni a fost stabilit la 732 . Parlamentului European i s-a conferit competența, la fel ca și Consiliului, Comisiei și statelor membre, să conteste 
în justiţie acte ale Consiliului, ale Comisiei sau ale Băncii Centrale Europene pentru motive de incompetență, de încălcare a unor norme fundamentale de procedură, de încălcare a tratatului sau a oricărei norme de drept privind aplicarea acestuia sau de abuz de putere. În urma unei propuneri a Comisiei, articolul 191 a fost transformat într-un temei juridic operaţional care trebuie să permită adoptarea, prin procedura de codecizie, a statutului partidelor politice de la nivel european şi a regulilor legate de finanțarea acestora.

Competențele legislative ale Parlamentului au fost sporite printr-o ușoară extindere a domeniului de aplicare al procedurii de codecizie și prin dispoziții care impun ca Parlamentul să își dea avizul conform în vederea instituirii unei cooperări consolidate în domeniile acoperite de codecizie. De asemenea, Parlamentului i se solicită avizul atunci când Consiliul se pronunță cu privire la riscul unei încălcări grave a drepturilor fundamentale într-un stat membru.

Curții de Justiție a Uniunii Europene i s-a acordat posibilitatea de a se reuni în diferite formule: în camere (formate din trei sau cinci judecători), în Marea Cameră (11 judecători) sau în ședință plenară. Numărul de avocaţi generali poate fi crescut printr-o decizie a Consiliului, adoptată în unanimitate. Curtea de Justiție își păstrează competența cu privire la hotărârile preliminare, dar, în temeiul statutului său, poate transmite Tribunalului de Primă Instanță alte cauze decât cele enumerate la articolul 225 din Tratatul CE. Competențele Tribunalului de Primă Instanță au fost extinse pentru a include anumite categorii de hotărâri preliminare. Camerele jurisdicționale pot fi instituite printr-o decizie a Consiliului, adoptată în unanimitate. Toate aceste dispoziţii legate de funcționare, în special competențele Tribunalului, au fost de atunci înainte stabilite chiar în tratat.

Deși un număr considerabil de noi politici și dispoziții (27) necesitau votul cu majoritate calificată în Consiliu, codecizia a fost extinsă doar la câteva domenii minore (fostele articole 13, 62, 63, 65, 157, 159 și 191 din Tratatul CE), iar pentru fostul articol 161 se impunea procedura de aviz conform al Parlamentului. Ca și Tratatul de la Amsterdam, Tratatul de la Nisa cuprinde dispoziții generale care se aplică tuturor domeniilor de cooperare consolidată și dispoziții specifice pilonului în cauză. În timp ce Tratatul de la Amsterdam prevedea posibilitatea cooperării consolidate doar în cadrul primului și celui de al treilea pilon, Tratatul de la Nisa prevedea acest lucru în cadrul tuturor celor trei piloni. De asemenea, Tratatul de la Nisa a mai adus încă două modificări: sesizarea Consiliului European nu mai era posibilă, iar conceptul de „termen rezonabil” a fost clarificat. Avizul conform Parlamentului era necesar în toate cazurile în care cooperarea consolidată viza o chestiune acoperită de procedura de codecizie.

La articolul 7 din TUE a fost adăugat un nou alineat care reglementa situațiile în care exista un „risc clar” de încălcare a drepturilor fundamentale. Consiliul, hotărând cu o majoritate de patru cincimi din membrii săi și după obținerea avizului conform al Parlamentului European, avea competența de a stabili existența unui astfel de risc și de a adresa recomandări adecvate statului membru în cauză. A fost proclamată o Cartă a drepturilor fundamentale fără caracter obligatoriu [5].

$\mathrm{Ca}$ şi în cazul conferinţelor interguvernamentale anterioare, Parlamentul European a participat activ la pregătirile pentru Conferința Interguvernamentală din 2000, prezentându-și opiniile cu privire la agenda conferinţei şi la evoluţiile şi obiectivele acesteia. Parlamentul şi-a exprimat opinia și asupra fondului și implicațiilor judiciare ale Cartei drepturilor fundamentale. Parlamentul a insistat îndeosebi ca viitoarea Conferință Interguvernamentală să urmeze un proces transparent, deschis participării deputaților din Parlamentul European, a parlamentelor naționale și a Comisiei, precum și contribuțiilor din partea cetățenilor, urmând ca rezultatul acestuia să fie concretizat într-un document cu caracter constituțional.

În ceea ce privește Convenția privind viitorul Europei, în conformitate cu Declarația nr. 23 anexată la Tratatul de la Nisa, Consiliul European de la Laeken din 14 şi 15 decembrie 2001 a hotărât să organizeze o convenție care să reunească principalele părți interesate în cadrul unei dezbateri privind viitorul Uniunii Europene. Aceasta avea ca obiective pregătirea următoarei Conferințe Interguvernamentale cât mai transparent posibil și abordarea celor patru provocări majore privind evoluția pe viitor a Uniunii Europene: o mai bună distribuire a competențelor, simplificarea instrumentelor de acțiune ale Uniunii, o democrație consolidată și mai multă transparență și eficacitate, precum și elaborarea unei constituții pentru cetățenii europeni.

Convenția a fost formată dintr-un președinte (Valéry Giscard d'Estaing), doi vicepreședinți (Giuliano Amato și Jean-Luc Dehaene), 15 reprezentanți ai șefilor de stat sau de guvern din statele membre, 30 de deputaţi din parlamentele naţionale (câte doi din fiecare stat membru), 16 deputaţi din Parlamentul European și doi membri ai Comisiei Europene. Ţările candidate la aderare au putut participa la dezbatere în aceleași condiții și de pe poziții egale, însă nu au avut competența de a bloca consensul la care puteau ajunge statele membre. Astfel, Convenția a avut 105 membri în total. În afară de președinte și vicepreședinți, prezidiul era compus din nouă membri ai Convenției și un reprezentant invitat, ales de țările candidate. Prezidiul a avut rolul de a da un imbold Convenției, oferindu-i o bază de lucru.

Lucrările Convenției prevedeau o etapă de „,ascultare”, în care s-a urmărit identificarea așteptărilor și nevoilor statelor membre și ale cetățenilor europeni, o etapă în care ideile exprimate au fost studiate și o etapă de elaborare a recomandărilor pe baza sintezei rezultate în urma dezbaterilor. La sfârșitul anului 2002, cele 11 grupuri de lucru și-au prezentat concluziile Convenției. În timpul primei jumătăți a anului 2003, Convenția a elaborat și a dezbătut un text care a devenit proiectul de tratat de instituire a unei Constituții pentru Europa.

Partea I (principii și instituții, 59 de articole) și partea a II-a (Carta drepturilor fundamentale, 54 de articole) din tratat au fost prezentate Consiliului European de la Salonic, la 20 iunie 2003. Partea a III-a (politici, 338 de articole) și partea a IV-a (dispoziții finale, 10 articole) au fost prezentate Președinției italiene, la 18 iulie 2003. O 
Conferinţă Interguvernamentală ulterioară a adoptat textul la 18 iunie 2004. Chiar dacă acesta a suferit modificări considerabile, s-a menținut structura de bază a proiectului elaborat de Convenție. Totuşi, din cauza a două referendumuri cu rezultate negative, desfășurate în Franța și în Țările de Jos, procedura de ratificare a Tratatului de instituire a unei Constituţii pentru Europa nu a fost dusă la bun sfârșit [6].

Cea mai mare parte a observatorilor au considerat că impactul deputaților europeni în cadrul activităților Convenției a fost decisiv. Mai multe aspecte, cum ar fi desfășurarea Convenției la sediul Parlamentului și experiența de negociere într-un mediu internaţional a deputaților europeni, le-au permis acestora din urmă să aibă o puternică influență asupra dezbaterilor şi rezultatelor Convenției. De asemenea, acestea au contribuit în mod activ la formarea familiilor politice compuse din deputaţi în Parlamentul European și din deputaţi în parlamentele naționale. Prin urmare, Parlamentul a reușit să atingă un număr semnificativ dintre obiectivele sale iniţiale, cea mai mare parte dintre acestea fiind în prezent înscrise în Tratatul de la Lisabona [7].

Tratatul de la Lisabona de modificare a Tratatului privind Uniunea Europeană (TUE) și a Tratatului de instituire a Comunității Europene (TCE) (JO C 306, 17.12.2007), intrat în vigoare la 1 decembrie 2009 . Tratatul de la Lisabona a demarat sub forma unui proiect constituțional la sfârşitul lui 2001 (Declaraţia Consiliului European privind viitorul Uniunii Europene sau Declarația de la Laeken), urmat în 2002 şi 2003 de Convenția europeană care a elaborat Tratatul de instituire a unei Constituții pentru Europa (Tratatul constituţional) [7]. Procesul care a dus la elaborarea Tratatului de la Lisabona este rezultatul negativ a două referendumuri asupra Tratatului constituțional organizate în mai și iunie 2005, în urma cărora Consiliul European a decis să își ia o ,perioadă de reflecție” de doi ani. În final, în temeiul declarației de la Berlin din martie 2007, Consiliul European din 21-23 iunie 2007 a adoptat un mandat detaliat pentru o Conferință Interguvernamentală ulterioară, sub egida Președinției portugheze. Conferința Interguvernamentală și-a încheiat lucrările în octombrie 2007. Tratatul a fost semnat în cadrul Consiliului European de la Lisabona din 13 decembrie 2007 și a fost ratificat de toate statele membre ale Uniunii Europene.

Tratatul de instituire a Comunității Europene este redenumit „Tratatul privind funcționarea Uniunii Europene”, iar termenul „Comunitate” este înlocuit cu „Uniune” în tot textul. Uniunea ia locul Comunității, fiind succesorul juridic al acesteia. Tratatul de la Lisabona nu creează simboluri statale pentru Uniune, cum ar fi un steag sau un imn. Cu toate că nu mai poartă denumirea de tratat constituțional, noul text menține cele mai semnificative realizări. Tratatul de la Lisabona nu îi conferă Uniunii competențe exclusive suplimentare. $\mathrm{Cu}$ toate acestea, noul text modifică modul în care Uniunea Europeană își exercită competențele existente și anumite competențe (partajate) noi, încurajând participarea și protejarea cetățenilor, creând o nouă ordine instituțională și modificând procesele decizionale pentru mai multă eficacitate și transparenţă, asigurând astfel un nivel mai ridicat de control parlamentar și de răspundere democratică.

Spre deosebire de Tratatul Constituţional, Tratatul de la Lisabona nu conține niciun articol care să stabilească în mod oficial supremația dreptului Uniunii Europene asupra legislației naționale, dar la tratat a fost ataşată o declarație în acest sens (Declaraţia nr. 17), ce face referire la un aviz al Serviciului juridic al Consiliului ce reiterează jurisprudența constantă a Curții Europene de Justiţie pe această temă.

Tratatul de la Lisabona clarifică pentru prima dată competențele Uniunii, distingând trei tipuri de competențe: competența exclusivă, potrivit căreia Uniunea este singura care poate adopta dispoziții legislative, statele membre ocupându-se doar de punerea în aplicare; competența partajată, potrivit căreia statele membre au dreptul de a legifera și de a adopta măsuri obligatorii din punct de vedere juridic în cazul în care Uniunea nu şi-a exercitat competența și competența de sprijin, potrivit căreia Uniunea Europeană desfăşoară acțiuni de sprijin sau de completare a politicilor statelor membre. În prezent, competențele Uniunii pot fi redate statelor membre în cursul unei revizuiri a tratatului.

Tratatul de la Lisabona conferă Uniunii Europene personalitate juridică proprie. Prin urmare, Uniunea poate semna tratate internaționale în domeniile sale de competenţă și poate deveni membră a unor organizații internaționale. Statele membre pot semna doar acorduri internaționale compatibile cu legislația Uniunii Europene. Pentru prima dată, tratatul prevede, la articolul 50 din Tratatul asupra Uniunii Europene, o procedură oficială pe care trebuie să o urmeze statele ce doresc să se retragă din Uniunea Europeană conform cerințelor constituţionale.

Tratatul de la Lisabona încheie integrarea în cadrul primului pilon a ultimelor aspecte ale pilonului trei privind spaţiul de libertate, securitate și justiţie cooperarea polițienească și judiciară în materie penală. Fosta structură interguvernamentală nu mai există, actele din acest domeniu fiind adoptate prin procedura legislativă ordinară (majoritate calificată și codecizie) și, sub rezerva unor dispoziții contrare, utilizând instrumentele juridice ale metodei comunitare (regulamente, directive și decizii).

De la intrarea în vigoare a Tratatului de la Lisabona, Parlamentul European poate propune modificări ale tratatelor; anterior, puteau face astfel de propuneri Consiliul, guvernele statelor membre sau Comisia. In mod normal, astfel de propuneri ar impune convocarea Convenției, care ar recomanda amendamente unei Conferințe Interguvernamentale. $\mathrm{Cu}$ toate acestea, Consiliul European poate decide, după obținerea aprobării Parlamentului, să nu convoace o convenție. Ar urma să fie apoi convocată o Conferință Interguvernamentală, care să adopte amendamentele la tratate de comun acord. $\mathrm{Cu}$ toate acestea, tratatele pot fi revizuite şi fără convocarea unei Conferințe Interguvernamentale, prin proceduri simplificate de revizuire, atunci când este vorba de dispoziții privind politicile și acțiunile interne ale Uniunii. În acest caz, revizuirea ar fi adoptată ca decizie a Consiliului European, dar ar putea fi supusă normelor naționale de 
ratificare.

Tratatul de la Lisabona enunță trei principii fundamentale: principiul egalităţii democratice, principiul democraţiei reprezentative și principiul democrației participative. Democraţia participativă îmbracă forma unei noi inițiative a cetățenilor [8]. Carta drepturilor fundamentale a Uniunii Europene nu este inclusă ca atare în Tratatul de la Lisabona, dar articolul 6 alineatul (1) din TUE îi conferă forță juridică obligatorie, acordându-i o valoare juridică egală cu cea a tratatelor [9].

Procesul de aderare a Uniunii Europene la Convenția europeană a drepturilor omului (CEDO) a fost lansat odată cu intrarea în vigoare, la 1 iunie 2010, a Protocolului nr. 14 la CEDO, care permite nu doar statelor, ci şi organizațiilor internaționale, şi deci şi Uniunii Europene, să devină semnatare ale CEDO. Este totuși necesar ca aderarea să fie ratificată atât de toate statele care sunt parte la CEDO, cât și de Uniunea Europeană. Negocierile dintre reprezentanții Consiliului Europei şi, respectiv, ai Uniunii Europene au dus la finalizarea unui proiect de acord în aprilie 2013. Curtea de Justiție a Uniunii Europene a considerat însă, în Avizul 2/2013, că proiectul respectiv este incompatibil cu articolul 6 din Tratatul Uniunii Europene. Vor fi necesare noi negocieri înainte de aderare.

În conformitate cu articolul 14 alineatul (2) din Tratatul Uniunii Europene, Parlamentul European „este compus din reprezentanții cetățenilor Uniunii”, nu din reprezentanții „,populației statelor”(articolul 189 din Tratatul CE). Competențele legislative ale Parlamentului European s-au extins prin noua procedură legislativă ordinară, care înlocuiește fosta procedură de codecizie. Printre altele, procedura legislativă ordinară se aplică acum în peste 40 de domenii noi de politică, numărul total crescând la 73. Procedura de aviz conform există în continuare sub forma procedurii de aprobare, iar procedura de consultare rămâne neschimbată. Noua procedură bugetară creează o egalitate deplină între Parlament și Consiliu în ceea ce privește aprobarea bugetului anual. Parlamentul European trebuie să își dea acordul asupra noului cadru financiar multianual (procedura de aprobare). De asemenea, Parlamentul European este cel care numește acum președintele Comisiei, cu majoritatea membrilor săi, la propunerea Consiliului European, care este obligat să aleagă un candidat cu majoritate calificată pe baza rezultatului alegerilor europene. Parlamentul European continuă să aprobe colegiul comisarilor (Comisia). Numărul maxim de deputați europeni a fost stabilit la 751. Numărul maxim de locuri pentru un stat membru a scăzut la 96, iar numărul minim a crescut la 6 . Germania și-a păstrat cei 99 de deputaţi până la alegerile din 2014.

Tratatul de la Lisabona recunoaște în mod oficial Consiliul European ca instituție a Uniunii Europene care trebuie să ofere Uniunii ,impulsurile necesare dezvoltării acesteia” și să definească ,orientările și prioritățile politice generale" ale acesteia. Consiliul European nu exercită funcții legislative. O președinție pe termen lung înlocuiește sistemul anterior de rotație la şase luni. Președintele este ales cu majoritate calificată de Consiliul European pentru un mandat reînnoibil de 30 de luni.
Acest sistem ar trebui să îmbunătățească continuitatea și coerența lucrărilor Consiliului European. Președintele este, în egală măsură, reprezentantul extern al Uniunii, fără a aduce atingere sarcinilor Înaltului Reprezentant al Uniunii pentru afaceri externe și politica de securitate (a se vedea mai jos). Vicepreședintele Comisiei Europene sau Înaltul Reprezentant al Uniunii pentru Afaceri Externe şi Politica de Securitate este numit cu majoritate calificată de Consiliul European, cu acordul președintelui Comisiei și este responsabil de politica externă și de securitate comună a Uniunii Europene, având dreptul de a înainta propuneri. Acesta prezidează Consiliul Afaceri Externe și, în paralel, este vicepreședinte al Comisiei. Vicepreședintele Comisiei Europene sau Înaltul Reprezentant al Uniunii pentru Afaceri Externe şi Politica de Securitate este asistat de Serviciul European de Acțiune Externă, format din personal de la Consiliu, de la Comisie și din serviciile diplomatice naționale.

În segmentul de activitate al Consiliului de Miniștri al Uniunii Europene, Tratatul de la Lisabona menține principiul dublei majorități în cadrul voturilor (cetățeni și state membre). Cu toate acestea, normele anterioare de vot au rămas valabile până în noiembrie 2014. Între 1 noiembrie 2014 și 31 martie 2017 se aplică noile norme, însă orice stat membru poate solicita utilizarea sistemului anterior de ponderare a voturilor. Majoritatea calificată este obținută atunci când o propunere este susținută de $55 \%$ dintre membrii Consiliului, reunind cel puțin $65 \%$ din populația Uniunii. Atunci când Consiliul nu hotărăște pe baza unei propuneri a Comisiei sau a Vicepreședintelui Comisiei Europene sau Înaltul Reprezentant al Uniunii pentru Afaceri Externe și Politica de Securitate, majoritatea necesară a statelor membre crește la $72 \%$. Pentru a putea bloca un act legislativ, este necesar ca cel puțin patru state membre să voteze împotrivă. Un nou mecanism, inspirat de „,compromisul de la Ioannina”, va permite ca membri ai Consiliului reprezentând 75\% (55\% începând cu 1 aprilie 2017) din numărul de state membre necesare pentru a constitui o minoritate de blocare să solicite, ,într-un termen rezonabil”, reexaminarea unei propuneri.

Consiliul se întrunește în ședință publică atunci când deliberează și votează un proiect de act legislativ. În acest scop, fiecare sesiune a Consiliului este divizată în două părți, consacrate deliberărilor privind actele legislative ale Uniunii, respectiv activităților fără caracter legislativ. Președinția Consiliului va continua să se schimbe o dată la șase luni, însă constituirea unor grupuri prestabilite de câte trei state membre care vor asigura președinția timp de 18 luni va asigura o mai bună continuitate a lucrărilor. În mod excepțional, Consiliul Afaceri Externe este prezidat întotdeauna de Vicepreședintele Comisiei Europene sau Înaltul Reprezentant al Uniunii pentru Afaceri Externe și Politica de Securitate. Deoarece președintele Comisiei este acum ales şi numit pe baza rezultatului alegerilor europene, legitimitatea sa politică crește. Președintele este responsabil de organizarea internă a colegiului (numirea comisarilor, distribuirea portofoliilor, cererile de demisie în anumite circumstanțe).

$\mathrm{Cu}$ excepția politicii externe și de securitate comună, toate activităţile Uniunii sunt acum de competența Curții. 
Numărul avocaților generali poate crește de la opt la unsprezece. Se pot institui tribunale specializate cu acordul Parlamentului. Accesul la Curte pentru persoanele fizice este simplificat. Se prevede instituirea unui parchet european pentru a cerceta, a urmări şi a deferi justiției infracțiunile care aduc atingere intereselor financiare ale Uniunii.

Mai multe „clauze-pasarelă” permit modificarea procesului decizional cu trecerea de la votul în unanimitate la votul cu majoritate calificată și schimbarea procedurii de consultare cu procedura legislativă ordinară [10]. În domeniile în care Uniunea nu dispune de competențe exclusive, un minim de nouă state membre pot institui o cooperare consolidată. Acțiunile de cooperare consolidată trebuie autorizate de Consiliu, după aprobarea de către Parlamentul European. Pentru chestiunile din domeniul politicii externe şi de securitate comună se aplică unanimitatea.

Tratatul de la Lisabona consolidează considerabil principiul subsidiarității prin implicarea parlamentelor naționale în procesul decizional [11]. Au fost introduse câteva domenii noi sau extinse de politici în domeniul mediului, care include acum combaterea schimbărilor climatice, și în domeniul energiei, cu referiri noi la solidaritate și securitate, precum și la interconectarea aprovizionării. În plus, drepturile de proprietate intelectuală, sportul, spațiul, turismul, protecția civilă și cooperarea administrativă pot face în prezent obiectul unor eventuale decizii ale UE.

În domeniul politicii europene de securitate și apărare comună [12], Tratatul de la Lisabona introduce o clauză de apărare reciprocă, conform căreia toate statele membre sunt obligate să sprijine un stat membru în caz de atac. O clauză de solidaritate stipulează că Uniunea și fiecare dintre statele sale membre trebuie să acorde asistență, prin toate mijloacele posibile, unui stat membru afectat de o catastrofă naturală ori de un atac terorist. O „cooperare structurată permanentă” este disponibilă tuturor statelor membre care se angajează să participe la programele

europene în materie de echipamente militare şi să furnizeze unități de luptă disponibile pentru acțiuni imediate. Pentru instituirea unei astfel de cooperări, este necesar un vot cu majoritate calificată în Consiliu, după consultarea Vicepreședintelui Comisiei Europene sau Înaltul Reprezentant al Uniunii pentru Afaceri Externe și Politica de Securitate [13].

\section{Referințe bibliografice:}

1. Tratatele de formare a Comunităţii Europene. http://www.europarl.europa.eu/aboutparliament /ro/displayFtu.html?ftuId=FTU_1.1.1.html (vizitat 12.09.2021).

2. Politica externă: obiective, instrumente, rezultate: http://www.europarl.europa.eu/about parliament/ro/displayFtu.html?ftuId=FTU_6.1.1.html(vizitat 01.10.2021).

3. Un spaţiu de libertate, securitate şi justiţie: aspecte generale. http://www.europarl.europa.eu/ aboutparliament/ro/displayFtu.html?ftuId=FTU_5.12.1.html(vizitat 29.09.2021).

4. Petr Novak. Tratatele de laMaastricht şi Amsterdam. http://www.europarl.europa.eu/about parliament/ro/displayFtu.html?ftuId=FTU_1.1.3.html(vizitat 24.09.2021).

5. Carta drepturilor fundamentale http://www.europarl.europa.eu/aboutparliament/ro/displayFtu. html?ftuId=FTU_1.1.6.html(vizitat 25.09.2021).

6. Tratatul de la Lisabona. http://www.europarl.europa.eu/aboutparliament/ro/displayFtu.html? ftuId=FTU_1.1.5.html(vizitat 10.10.2021).

7. Petr Novak. Tratatul de la Nisa şi Convenţia privind viitorul Europei. Error! Hyperlink reference not valid..eu/aboutparliament/ro/displayFtu.html?ftuId=FTU_1.1.4.html 8. Iniţiativa cetăţenească europeană. http://www.europarl.europa.eu/aboutparliament/ro/display Ftu.html?ftuId=FTU_2.1.5.html(vizitat 22.09.2021).

9. Carta drepturilor fundamentale. http://www.europarl.europa.eu/aboutparliament/ro/display Ftu.html?ftuId=FTU_1.1.6.html(vizitat 11.10.2021).

10. Proceduri decizionale interguvernamentale. http://www.europarl.europa.eu/aboutparliament /ro/displayFtu.html?ftuId=FTU_1.4.2.html(vizitat 12.09.2021).

11. Parlamentul European: cooperare cu parlamentele naţionale. http://www.europarl.europa.eu /aboutparliament/ro/displayFtu.html?ftuId=FTU_1.3.5.html(vizitat 12.09.2021).

12. Politica de securitate şi apărare comună. http://www.europarl.europa.eu/aboutparliament/ro/ displayFtu.html?ftuId=FTU_6.1.2.html (vizitat 22.09.2021).

13. Petr Novak. Rosa Raffaelli. Tratatul de la Lisabona. http://www.europarl.europa.eu /atyour service/ro/displayFtu.html?ftuId=FTU_1.1.5.html (vizitat 27.09.2021). 